Sylwia Psica

\title{
Oświeceniowa wizja nauki \\ w ujęciu Józefa Sołtykowicza, jako przykład refleksji filozoficznej z kręgu Towarzystwa Naukowego Krakowskiego
}

Pochwała nauki na gruncie polskiej literatury pojawiła się dość wcześnie, bo już w średniowieczu, jednak podkreślenia jej społecznej roli dokonało dopiero oświecenie ${ }^{1}$. Działacze tej epoki za swój cel uznali między innymi reformę edukacji, która w drugiej połowie XVIII wieku była przestarzała. We wszystkich trzech ośrodkach akademickich (Krakowie, Lwowie i Wilnie) ceniono scholastykę i wykładano filozofię perypatetycko-tomistyczna ${ }^{2}$. Z powodu krytykowania przez wykładowców uniwersyteckich oświeceniowej myśli przenikajacej do Polski z zagranicy intelektualna stolica Polski stała się Warszawa $^{3}$. Nie posiadała ona wówczas własnej szkoły wyższej, ale poprzez założenie Collegium Nobilium, działania Komisji Edukacji

1 Patrz: B. Suchodolski, Kilka refleksji nad dziejami nauk przyrodniczych $w$ Polsce, w: Zarys dziejów nauk przyrodniczych w Polsce, red. J. Kuryłowicz i in., Warszawa 1983, s. 30. Autor odwołuje się do treści aktu fundacyjnego Uniwersytetu Krakowskiego oraz przytacza fragment traktatu o istocie prawa Stanisława Zaborowskiego, w którym nauka została porównana do światła oświecającego całe królestwo.

2 Patrz: J. Skoczyński, J. Woleński, Historia filozofii polskiej, Kraków 2010, s. 200-201.

3 Patrz: J. Skoczyński, J. Woleński, Historia filozofii polskiej, dz. cyt., s. 201. 
Narodowej i Towarzystwa do Ksiag Elementarnych tacy działacze, jak Stanisław Konarski, Hugo Kołłątaj czy Grzegorz Piramowicz, rozpoczęli przemiany edukacyjne, które sprawiły, że „w początkach XIX w. szkoły polskie kształciły na normalnym europejskim poziomie" ". Zły stan edukacji wynikał również z niskiego poziomu badań naukowych, których rozwój i unowocześnianie były jednymi z celów oświeceniowych. Były one realizowane między innymi przez towarzystwa naukowe, których gwałtowny przyrost nastapił w XVIII wieku. W czasach saskich o ożywieniu życia kulturalnego świadczą powstałe w Gdańsku towarzystwa naukowe: Societas Litteraria (1720) i Naturforschende Gesellschaft (1742) ${ }^{5}$. Dynamiczny rozwój pozauniwersyteckich organizacji naukowych nastapił jednak w okresie stanisławowskim, gdy zaczęły działać: Warszawskie Towarzystwo Fizyczno-Chemiczne (1767), Towarzystwo Ludzi Dobro Publiczne i Nauki Kochających (1771, Warszawa), Związek Filantropów (1787, Kraków), Towarzystwo Krytyczne (1788, Warszawa), Warszawskie Towarzystwo Przyjaciół Nauk (1800) i Towarzystwo Naukowe (1816, Kraków) ${ }^{6}$. Pierwsze posiedzenie publiczne ostatniego z wymienionych towarzystw odbyło się 25 lutego 1816 roku, ale za datę powstania TNK uznaje się rok 1815, gdy Rada Rektorska Uniwersytetu Jagiellońskiego uchwaliła projekt statutu, a władze Wolnego Miasta Krakowa zatwierdziły akt jego powołania ${ }^{7}$. Danuta Rederowa zwróciła także uwagę, że towarzystwo to, jako drugie z kolei w kraju, miało charakter ogólny, następnie „w latach 1832-1856 było jedynym tego rodzaju na ziemiach polskich"8, zaś w 1872 roku zostało przekształcone w pierwszą polską akademię nauk. Autorka przypomina również, że prekursorską myśl ustanowienia towarzystwa naukowego w ramach wydziałów uniwersyteckich powzią Hugo Kołłątaj, który w 1776 roku przygotowywał reformę Akademii

\footnotetext{
J. Skoczyński, J. Woleński, Historia filozofii polskiej, dz. cyt., s. 201.

Patrz: J. Skoczyński, J. Woleński, Historia filozofii polskiej, dz. cyt., s. 202.

6 Patrz: J. Skoczyński, J. Woleński, Historia filozofii polskiej, dz. cyt., s. 202.

7 Patrz: Kalendarium Towarzystwa Naukowego Krakowskiego, http://tnk. krakow.pl/o-towarzystwie/kalendarium/ (02.02.2019).

8 D. Rederowa, Powstanie i ustrój Towarzystwa Naukowego Krakowskiego (18151872), „Kwartalnik Historii Nauki i Techniki” t. 14/1 (1969), s. 53.
} 
Krakowskiej ${ }^{9}$ Z powodu sprzeciwu rządu porzucił pomysł, do którego powrócił prawie 30 lat później, opracowując w 1809 roku Urzqdzenie Szkoty Głównej Krakowskiej. Planowane przez niego otwarcie Instytutu Akademickiego zostało jednak zablokowane przez władze ${ }^{10}$, a ostatecznie powstanie towarzystwa umożliwiły starania Samuela Bandtkiego i Walentego Litwińskiego. Warto tu również dodać, że obraz myśli filozoficznej uczonych z kręgu Towarzystwa Naukowego Krakowskiego dotychczas nie doczekał się należytego opracowania. Wymaga to uzupełnienia, gdyż można przypuszczać, że działalność uczonych z kręgu TNK znacznie wpłynęła na rozwój refleksji filozoficznej w Krakowie. Niestety okres XIX wieku często stereotypowo wpisywany jest $\mathrm{w}$,sztywne ramy jasno wyznaczonych epok" ${ }^{11}$, co wypacza światopogląd członków TNK, których myśli nie można jednoznacznie przyporządkować ani do filozofii romantycznej, ani do pozytywizmu warszawskiego. Szerokie spektrum zainteresowań tych uczonych, widoczne choćby w publikacjach na łamach rocznika TNK, można za to analizować w kontekście oddziaływania myśli oświeceniowej. W niniejszym artykule w taki sposób prześledzimy refleksję filozoficzną Józefa Sołtykowicza, zwracając jednocześnie uwagę na znaczenie jego rozważań dla rozwoju polskiej kultury naukowej.

\section{Tło wystąpienia Sołtykowicza}

Towarzystwo Naukowe Krakowskie, którego członkiem od 1816 roku był Józef Sołtykowicz, za jeden ze swoich celów uważało rozwijanie badań naukowych w Krakowie, co czyniono pomimo wielu

9 Patrz: D. Rederowa, Powstanie i ustrój Towarzystwa Naukowego Krakowskiego (1815-1872), dz. cyt., s. 56.

10 Patrz: D. Rederowa, Powstanie i ustrój Towarzystwa Naukowego Krakowskiego (1815-1872), dz. cyt., s. 56.

11 P. Polak, Między koniecznościa a utopia. Józefa Kremera koncepcja filozofii przyrody w kontekście szybko rozwijajacej się nauki, w: Genus Vitae. Ksiega pamiatkowa dedykowana panu profesorowi Marianowi Józefowi Wnukowi, red. S. Janeczek, Z. Wróblewski, A. Starościc, Lublin 2019, s. 258. 
niesprzyjających czynników ${ }^{12}$. Jego członkami byli profesorowie uczelni, a także powołani członkowie honorowi i korespondencyjni. Zadaniem Towarzystwa, jak głosił opracowany przed Samuela Bandtkiego Statut, było przyczynienie się do rozwoju wszelkich nauk, propagowanie wiedzy potrzebnej narodowi, „rozszerzenia światła, rozkrzewienia sztuk, przemysłu i kunsztów w Narodzie"13. Członkowie TNK uczestniczyli w comiesięcznych posiedzeniach, na których odczytywali swe prace, a niektóre z nich były następnie drukowane w „Rocznikach” Towarzystwa, które zaczęły wychodzić od 1817 roku. Towarzystwo utrzymywało się głównie ze składek członkowskich, co w późniejszym czasie miało wpływ na czasowe wstrzymanie publikacji, ze względu na trudności materialne, a także małe zainteresowanie rocznikiem ze strony społeczeństwa ${ }^{14}$.

Podjęta przez Bandtkiego i Litwińskiego inicjatywa spotkań elity intelektualnej Krakowa odpowiadała zwyczajom tamtego okresu. W Europie XIX wieku wydawano wiele czasopism naukowych i podręczników, pojawiły się również nowoczesne przemysłowe laboratoria badawcze, które były ściśle związane z daną gałęzią przemysłu ${ }^{15}$. Stopniowo zawód naukowca zaczynał być doceniany, szczególnie że sprzyjał on rozwiązywaniu zagadnień praktycznych. Dlatego zaczęto tworzyć instytuty kształcące inżynierów lub specjalistów różnych dziedzin, których zadaniem było między innymi rozwiązywanie aktualnych problemów gospodarczych i politycznych ${ }^{16}$. Kwestie

12 Z. Skubała-Tokarska, Organizacja nauki w Polsce, w: Zarys dziejów nauk przyrodniczych $w$ Polsce, red. J. Kuryłowicz i in., Warszawa 1983, s. 73.; W 1856 r. Towarzystwo usamodzielniło się i po odłączeniu się od Uniwersytetu działało jako Cesarsko-Królewskie Towarzystwo Naukowe Krakowskie, a w latach 1871-1873 zostało przekształcone w Akademię Umiejętności.

13 Statut Towarzystwa Naukowego z Uniwersytetem Krakowskim złaczonego, http://tnk.krakow.pl/o-towarzystwie/kalendarium/\#/images/big/kalendarium/img2 . jpg (02.02.2019).

14 Patrz: J. Michalski, Warunki rozwoju nauki polskiej w latach 1795-1862, w: Historia nauki polskiej, t. III, red. B. Suchodolski, Wrocław 1977, s. 143.

15 Por.: H. Gurgul, Zarys historii fizyki. Od starożytności do XX wieku. Skrypt dla studentów fizyki, Szczecin 1993, s. 139.

16 Por.: H. Gurgul, Zarys historii fizyki. Od starożytności do XX wieku. Skrypt dla studentów fizyki, dz. cyt., s. 138-139. Jak dodaje autor, postęp ten nie zawsze 
te wydają się nadal aktualne, szczególnie w obliczu współczesnych postulatów rozwoju kierunków technicznych, specjalizacji nauki i fragmentaryzacji przekazywanej wiedzy ${ }^{17}$.

W będącej pod zaborami Polsce działanie polegające na rozpowszechnianiu i pogłębianiu wiedzy napotkało przeszkody natury politycznej. Pomimo starań osób zainteresowanych rozwojem nauki wiele planów nie udało się wcielić w życie. Doświadczył tego, opracowujacy strukturę organizacyjną Szkoły Głównej, Hugo Kołłątaj. Jego koncepcje dotyczące rozwijania badań naukowych nie zostały zrealizowane, gdyż Izba Edukacyjna Księstwa Warszawskiego główna uwagę zwracała na sprawy kształcenia specjalistów potrzebnych dla rozwoju gospodarczego kraju ${ }^{18}$. Z czasem sytuacja jeszcze bardziej się pogorszyła. W latach 1821, 1823, 1833 władze austriackie narzuciły Uniwersytetowi Krakowskiemu trzy kolejne statuty, ograniczając w ten sposób jego autonomię, niezależnie myślącym polskim profesorom odebrano możliwość prowadzenia zajęć, a o obsadzie katedr w Krakowie zaczą decydować uniwersytet wiedeński ${ }^{19}$. Do zaostrzenia sytuacji przyczyniła się między innymi działalność Stanisława Wodzickiego, który w Uniwersytecie dostrzegał „źródło niebezpiecznych tendencji wolnościowych" ${ }^{20}$. Wykorzystujac panująca sytuację polityczna przedstawiał on zaborcom, w jak najgorszym świetle profesorów krakowskich. Krytykował nadmierne według niego rozbudowanie szkolnictwa średniego, a zwłaszcza niższego, „w czym widział przejaw «edukomanii» zagrażającej porządkowi społecznemu przez

następował bezkonfliktowo czego przykładem jest zachowanie Karola Babbage, który był zmuszony wystapić wraz z grupa młodych uczonych z krytyką rządu i Royal Society, gdyż instytucja ta nie wypełniała swoich zadań względem nauki. Założyli oni w $1831 \mathrm{r}$. The British Association for the Advancement of Science (Zjednoczenie Brytyjskie dla Popierania Nauki) dzięki czemu byli w stanie popularyzować wiedzę i jednocześnie kierować pracami badawczymi i finansować je.

17 Por.: P. Polak, 19th Century Beginnings of the Kraków Philosophy of Nature, w: Philosophy in Science. Methods and Applications, Kraków 2011, s. 332.

18 Z. Skubała-Tokarska, Organizacja nauki w Polsce, dz. cyt., s. 72-73.

19 B. Średniawa, Część II. Reforma i jej nastęstwa, w: Historia filozofii przyrody i fizyki w Uniwersytecie Jagiellońskim, Warszawa 2001, s. 35.

20 Cytuję za: J. Michalski, Warunki rozwoju nauki polskiej w latach 1795-1862, dz. cyt., s. 138 . 
odrywanie ludzi z «klas niższych» od ich obowiązków i zaszczepianie w ich umysłach niebezpiecznego fermentu" 21 .

W tym kontekście wygłaszane przez Józefa Sołtykowicza, w latach 1817-1826, cztery rozprawy pt. Nad przyczynami uwłaczajacych Naukom mniemań, odradzajacych się $w$ różnych Wiekach Świata wpisuja się w aktualne spory polityczno-społeczne w znaczacy sposób oddziałujące na rozwój edukacji w Krakowie i utrzymanie, za pomocą nauki i filozofii, tożsamości narodowej ${ }^{22}$. W niniejszym artykule omówione zostaną dwie pierwsze rozprawy, opublikowane na łamach „Rocznika Towarzystwa Naukowego z Uniwersytetem Krakowskim połaczonego" w 1818 i 1820 roku. Poruszaja one szerokie spektrum zagadnień dotyczących wartości nauki, jej zadań, sposobów popularyzacji, ale także zagrożeń, jakie napotykali na swej drodze ludzie ceniący wiedzę i mądrość. Sołtykowicz nie poprzestał na analizie użyteczności zdobywanej wiedzy, lecz podją filozoficzny namysł nad źródłami działalności naukowej, stawiając również wciąż aktualne pytania o relacje pomiędzy wiarą a racjonalnymi rozważaniami. Jego prace dają możliwość przyjrzenia się tekstom powstałym w epoce przejściowej pomiędzy oświeceniem a romantyzmem. Jak bowiem zaznacza Jan Woleński, jest rzeczą sporna, jak długo trwało oświecenie w Polsce „czy do końca XVIII w., czy też nawet do 1830 r., a więc do czasów, gdy w Wielkiej Brytanii, Francji i Niemczech okres ten już całkowicie należał do przeszłości” ${ }^{23}$. Niejasność ta podkreśla współistnienie i ścieranie się ze sobą dwóch odmiennych tendencji światopoglądowych, a także sporów ideologicznych, których ślad możemy odnaleźć w rozprawach wspomnianego autora. Skupimy się tutaj tylko na ich dwóch pierwszych częściach, ponieważ w kolejnych wystapieniach - na posiedzeniach TNK w 1822 i 1826 roku - Sołtykowicz rozważał przede wszystkim cechy charakteryzujące prawdziwego uczonego oraz wady ludzi nauki, ze szczególnym

21 J. Michalski, Warunki rozwoju nauki polskiej w latach 1795-1862, dz. cyt., s. 138 .

22 Patrz: P. Polak, Między koniecznościa a utopiq. Józefa Kremera koncepcja filozofii przyrody w kontekście szybko rozwijajacej się nauki, dz. cyt., s. 257-258

23 J. Woleński, Oświecenie, w: Historia filozofii polskiej, red. J. Skoczyński, J. Woleński, Kraków 2010, s. 199. 
uwzględnieniem niewłaściwego używania przez nich posiadanej inteligencji. Ze względu na szczegółowość omawianych zagadnień rozprawy te wymagają osobnego opracowania, co przekracza ramy niniejszego artykułu. Wszystkie wspomniane cztery teksty zostały łącznie opublikowane w 1828 roku pt. Rozprawa nad przyczynami uwłaczajacych Naukom mniemań, odradzajacych się $w$ różnych wiekach świata ${ }^{24}$.

\section{Józef Sołtykowicz jako kontynuator idei oświeceniowych}

Józef Sołtykowicz urodził się w 1762 roku, w rodzinie drobnoszlacheckiej. Wzrastał zatem i kształtował swoją osobowość w okresie oświecenia, silnie angażując się nie tylko w życie naukowe, ale także polityczne Krakowa. W 1778 (lub 1780) roku uzyskał on tytuł doktora filozofii, zaś podczas wieloletniej pracy pedagogicznej nauczał między innymi prawa natury, prawa politycznego, ekonomii politycznej, nauki moralnej i języka francuskiego ${ }^{25}$. W późniejszym czasie został on profesorem prawa i dziekanem Wydziału Filozoficznego w Szkole Głównej Krakowskiej oraz senatorem Rzeczpospolitej Krakowskiej ${ }^{26}$. Silnie angażował się w działalność patriotyczna: był zwolennikiem Konstytucji 3 maja, w 1794 roku podczas powstania kościuszkowskiego należał „do najbardziej czynnych jego działaczy w Krakowie”27, później natomiast wspierał Kołłątaja w pracach nad statutem Szkoły Głównej Krakowskiej. Jego zaangażowanie polityczne nie ustawało również wówczas, gdy jako przedstawiciel gminy wielokrotnie wypowiadał się podczas posiedzeń Izby Reprezentantów Rzeczpospolitej Krakowskiej $^{28}$.

24 J. Sołtykowicz, Rozprawa nad przyczynami uwłaczajacych Naukom mniemań, odradzajacych się w różnych wiekach świata, Kraków 1828.

25 H. Wereszycka, E. Orman-Michta, Józef Florian Soltykowicz, http://ipsb.nina. gov.pl/a/biografia/jozef-florian-soltykowicz (25.09.2018).

26 Patrz: H. Wereszycka, E. Orman-Michta, Józef Florian Sottykowicz, dz. cyt.

27 H. Wereszycka, E. Orman-Michta, Józef Florian Sołtykowicz, dz. cyt.

28 Patrz: H. Wereszycka, E. Orman-Michta, Józef Florian Sottykowicz, dz. cyt. 
Postulowany przez Józefa Sołtykowicza stosunek do nauki wynikał z jego zakorzenienia $\mathrm{w}$ myśli oświecenia, z doświadczenia osobistych trudności w wprowadzaniu reform szkolnictwa, ale prawdopodobnie - jak zauważył Bogdan Suchodolski - także z inspiracji dziełem Marcina Świątkowskiego ${ }^{29}$. Uczony ten poznał główne tendencje ówczesnego przyrodoznawstwa podczas studiów w Niemczech, gdzie kształcił się pod kierunkiem Christiana Wolffa. Jego publikacja pt. Polski herold naukowej prawdy była wyjątkowa na tle kształtującej się w Polsce kultury oświecenia, gdyż stanowiła pierwszą próbę „ustalenia dominującej roli nauki w życiu ludzi, państwa i społeczeństwa, w działalności wychowawczej”30. Obaj autorzy, żyjąc na przełomie XVIII i XIX wieku, byli świadkami szybkiego rozwoju takich dziedzin fizyki, jak mechanika, optyka czy termodynamika ${ }^{31}$. Były to nauki, którym towarzyszył rozwój gospodarki i przemysłu, a zatem nauka miała coraz większe znaczenie praktyczne. Prężnie rozwijał się w tym czasie Uniwersytet w Berlinie, utworzony w 1809 r. z inicjatywy i według koncepcji Wilhelma von Humboldta. Uczelnia ta stała się wzorem pod względem organizacyjnym dla wielu uniwersytetów, które zaczęły przejmować jego strukturę ${ }^{32}$, co doprowadziło do szybkiego rozwoju nauki w Niemczech. Rozwój nauki polskiej - nie tylko ze względu na zabory - postępował o wiele wolniej niż w innych państwach. Dodatkowo by zdeprecjonować znaczenie polskich uniwersytetów zaborcy nadawali im nazwy szkół wyższych - Uniwersytet Jagielloński nazywano Szkołą Główną a Uniwersytet Wileński - Szkołą Główną

29 Patrz: B. Suchodolski, Kilka refleksji nad dziejami nauk przyrodniczych $w$ Polsce..., dz. cyt., s. 30-33.

30 B. Suchodolski, Kilka refleksji nad dziejami nauk przyrodniczych $w$ Polsce..., dz. cyt., s. 33. Książkę wydano po łacinie w 1765 roku, w Berlinie i Wrocławiu, zaś po polsku dopiero w 1976 roku.

${ }_{31}$ Patrz: A. K. Wróblewski, Historia fizyki od czasów najdawniejszych do wspótczesności, Warszawa 2006, s. 19-391 oraz H. Gurgul, Zarys historii fizyki. Od starożytności do XX wieku. Skrypt dla studentów fizyki, dz. cyt., s. 136.

${ }^{32}$ H. Gurgul, Zarys historii fizyki. Od starożytności do XX wieku. Skrypt dla studentów fizyki, dz. cyt., s. 139. Warto tu wspomnieć, że pierwszeństwo wśród niemieckich uniwersytetów miała uczelnia w Getyndze. 
Wileńską ${ }^{33}$. W czasie półtorarocznej okupacji pruskiej Uniwersytet Krakowski przerwał prowadzenie działalności edukacyjnej, by wznowić ją w roku akademickim 1796/97, gdy Kraków został włączony do zaboru austriackiego ${ }^{34}$. W lipcu 1809 roku, w wyniku zwycięskiej kampanii Napoleona i po wkroczeniu wojsk polskich do Krakowa, pojawiła się szansa reorganizacji i spolszczenia Uniwersytetu Krakowskiego. Podjął się jej Hugo Kołłątaj, który rozpoczął tę zmianę od obsadzenia ważnych stanowisk przez ludzi, do których miał zaufanie $^{35}$ - jedną z takich osób był właśnie Józef Sołtykowicz. To on podczas konfliktu autora Listów Anonima z Izbą Edukacyjna Księstwa Warszawskiego wielokrotnie wspierał Kołłątaja, między innymi w mowie O stanie Akademii Krakowskiej napisanej dla księcia Fryderyka Augusta ${ }^{36}$.

Kołłątaj zmarł w 1812 roku, ale jego idee stosunkowo szybko zostały wcielone w życie przez kontynuatorów. Konstytucja Wolnego Miasta Krakowa zapewniała wówczas Uniwersytetowi i profesorom wysoką rangę społeczna. Przeznaczono dla nich dwa miejsca w senacie i trzy w Zgromadzeniu Reprezentantów, mieli oni również czynne prawo wyborcze, niezależnie od cenzusu majątkowego ${ }^{37}$. Jednak działalności osób ceniących tradycje Komisji Edukacji Narodowej przeszkadzały przekonania adwersarzy, którzy w Uniwersytecie dostrzegali „źródło niebezpiecznych tendencji wolnościowych”38.

${ }_{33}$ Patrz: H. Gurgul, Zarys historii fizyki. Od starożytności do XX wieku. Skrypt dla studentów fizyki, dz. cyt., s. 140.

${ }^{34}$ Patrz: J. Michalski, Warunki rozwoju nauki polskiej w latach 1795-1862, w: Historia nauki polskiej, dz. cyt., s. 123.

35 J. Michalski, Warunki rozwoju nauki polskiej w latach 1795-1862, dz. cyt, s. $125-126$.

${ }^{36}$ Patrz: J. Michalski, Warunki rozwoju nauki polskiej w latach 1795-1862, dz. cyt. Jak piszą Helena Wereszycka i Elżbieta Orman-Michta poszerzony tekst tej mowy, opatrzony bogatymi przypisami, wyszedł drukiem w 1810 roku pod tytułem: O stanie Akademii Krakowskiej od założenia jej w roku 1347 aż do teraźniejszego czasu, krótki wykład historyczny, stając się pierwszą pracą o historii uczelni i uzyskując wiele recenzji w prasie polskiej i zagranicznej.

${ }^{37}$ Patrz: J. Michalski, Warunki rozwoju nauki polskiej w latach 1795-1862, dz. cyt., s. 135-136.

${ }_{38}$ J. Michalski, Warunki rozwoju nauki polskiej w latach 1795-1862, dz. cyt., s. 138. 
Analizując genezę wystapienia Sołtykowicza należy wspomnieć również o bardziej uniwersalnym kontekście związanym z filozofią europejska. Przeciwko nauce, szerzej nawet całej nowoczesnej cywilizacji, wystapił wpływowy Jan Jakub Rousseau, którego popularność w Polsce odpowiadała ogólnoeuropejskim trendom. Ten francuski pisarz zyskał sobie przychylność Polaków nie tylko wrażliwością i śmiałością literackich zwierzeń, ale także poparciem dla niepodległości kraju wyrażonym w dziele Uwagi nad rzqdem Polski ${ }^{39}$. Konkursowy tekst Rousseau z 1750 roku pt. Rozprawa o naukach $i$ sztukach przyniosła mu ogromna popularność, ale także wywołała lawinę polemik. Jednym z pierwszych, który skrytykował poglądy autora Nowej Heloizy był mieszkający wówczas w Lotaryngii Stanisław Leszczyński; w 1770 roku podobnego zadania podjął się Jan Albertrandi, późniejszy prezes Towarzystwa Przyjaciół Nauk w Warszawie, zaś w 1778 roku koncepcje Rousseau uznał za szkodliwe społecznie profesor retoryki Szymon Wychowski ${ }^{40}$. Niegasnące oddziaływanie spuścizny Rousseau na wyobraźnię czytelników XIX wieku (sam autor zmarł w 1778 roku) z pewnością miało również pewien wpływ na podjęcie przez Józefa Sołtykowicza stanowczego sprzeciwu wobec poglądów francuskiego preromantyka. Polemice tej nie poświęcił on jednak osobnego działu, lecz wplótł ją pomiędzy inne rozważania na temat wartości nauki w określonych epokach.

Porządkując zróżnicowane refleksje Sołtykowicza na temat nauk zawarte we wspomnianych dwóch rozprawach, rozpocznę od przedstawienia omówionych przez autora źródeł działalności naukowej. Następnie poddam rozważaniom ukazane w tekstach relacje pomiędzy nauką a wiara, by przejść do analizy zaprezentowanej popularyzacji wiedzy, krytyki poglądów Rousseau oraz antropologicznych źródeł negatywnego obrazu nauki.

39 M. Ludwisiak, Postać Jana Jakuba Rousseau i jego wpływ na wspótczesnych, „Acta Universitatis Lodziensis. Folia Historica” 81 (2007), s. 100.

${ }^{40}$ M. Ludwisiak, Postać Jana Jakuba Rousseau i jego wpływ na wspótczesnych, dz. cyt., s. 101. 


\section{3. Źródła działalności naukowej}

Kluczowym zagadnieniem dla autora były źródła działalności naukowej. Pisarz dostrzegał je w przepełnionej mądrością naturze ludzkiej. Autor, zgodnie z duchem oświecenia, mądrość czynił tą cechą która odróżnia ludzi od zwierząt. Twierdził, że nauka jest dla umysłu tym, czym pokarm dla ciała i dlatego nie powinna nigdy ustawać: „poznawać wiecznie, i zawsze się uczyć na nowo!”⒈ W swojej analizie Sołtykowicz z jednej strony zalecał odnoszenie się z szacunkiem do dokonań starożytnych, z drugiej zaś jawi się jako empirysta, który zachęcał do poznawania świata nie tylko rozumem, ale także dostępnymi zmysłami. W ten sposób jego metoda argumentacyjna różni się od scholastycznej ${ }^{42}$, gdyż rezygnuje z apriorycznego sposobu poznawania rzeczywistości oraz szczegółowej analizy języka i terminologii.

W ujęciu członka TNK rozwój wiedzy ma czasem charakter rewolucyjny, jednak w większości przypadków, gdy podda się analizie przykłady z historii nauki, zauważamy cechy ewolucjonizmu. Kolejne pokolenia zawdzięczaja postęp w danej dziedzinie nauki swoim poprzednikom, rozwijają myśli już istniejące. Sołtykowicz podkreśla znaczenie tradycji w rozwoju nauki, dostrzegając w niej zorganizowane przedsięwzięcie przekraczające ramy działania poszczególnych jednostek, a nawet pokoleń. Sam autor czuje się współuczestnikiem takiego procesu pisząc:

czemuż bym więc miał upadać na sercu dlatego, iż nie przyszła jeszcze na mnie kolej być twórcą i wynalazca? że w pomysłach moich nie znalazł się jeszcze ten ostatni żywiołek, który dodany do istniejących już kombinacji, dać by zdołał byt czemuś nowemu w świecie uczonych ${ }^{43}$ ?

${ }^{41}$ J. Sołtykowicz, Rozprawa nad przyczynami uwłaczajacych Naukom mniemań, odradzajacych się $w$ różnych Wiekach Świata, „Rocznik Towarzystwa Naukowego z Uniwersytetem Krakowskim połączonego" III (1818), s. 256.

42 Warto zauważyć, że do reformy kołłątajowskiej na uniwersytetach i w szkołach prowadzonych przez innowierców dominowała scholastyka, a edukacja była przestarzała - patrz: J. Skoczyński, J. Woleński, Historia filozofii polskiej, dz. cyt., s. $200-201$.

43 J. Skoczyński, J. Woleński, Historia filozofii polskiej, dz. cyt., s. 200-201 
Kumulatywistyczna wizja rozwoju nauki jest typowa dla XIX wieku i podporządkowana została u Sołtykiewicza oświeceniowej wizji postępu. Analizując rozwój nauki, w dalszej części swojego wywodu autor zwracał również uwagę, że odkrycia naukowe potrafia również zaskoczyć badaczy, a w ten sposób świat jeszcze bardziej podkreśla swoją tajemniczość i nieprzewidywalność. Nauka, zgodnie z duchem oświecenia, miała zatem ukazywać i rozświetlać wszelkie tajemnice natury.

\section{Relacje pomiędzy nauką a wiarą}

W rozważaniach Sołtykowicza refleksja na temat źródeł działalności naukowej ściśle związana jest z myśla o celowości stworzenia człowieka przez Boga. To właśnie w boskim zamyśle upatrywał autor powodów, dla których człowiek jest istotą ciekawą świata i tam właśnie dostrzegał on źródła nauki. Twierdził on również, że nieustanne poszukiwanie wiedzy przez ludzi, chęć zdobycia coraz to nowszych informacji, uprawianie nauki to dowody na wypełnianie Bożej woli. $\mathrm{W}$ poglądzie tym widzimy próby połączenia refleksji naukowej z wiara. Wiedza nie prowadzi tutaj ani do deizmu, ani do ateizmu, ani wreszcie agnostycyzmu, znanych z francuskiego oświecenia. W ujęciu Sołtykiewicza - zapewne w jakiejś mierze reprezentatywnego dla środowiska TNK - istnienie nauki jest świadectwem Bożego planu wobec człowieka. Propagowana przez krakowskiego uczonego teistyczna wizja źródeł nauki jest interesującym przykładem specyfiki polskiego oświecenia, a szczególnie środowiska TNK.

W drugiej ze swoich rozpraw Sołtykowicz wprost przeciwstawił się poglądowi wiążącemu rozwój ateizmu z postępem naukowym. Twierdził on, że prawdziwa mądrość to uświadomienie sobie ogromu tajemnicy, jaką skrywa świat. W retorycznym pytaniu zwraca się on do członków towarzystwa czy moga podać choćby jedną osobę ze swojego grona, którą nauka oddaliła od Boga. Zastosowanie takiej argumentacji ad personam, choć zapewne podyktowane celami retorycznymi, stało się pośrednim dowodem na to, że środowisko TNK musiało zasadniczo podzielać teistyczną interpretację Sołtykowicza. 
Według profesora naukowiec lub filozof, który poświęcił swoje życie zdobywaniu wiedzy jest świadomy tego, że życie kilku pokoleń to za mało by odkryć zamysł Stwórcy zapisany w konstrukcji świata. W wizji tej nauka staje się więc drogą do poznania Boga, nauka jest więc swoistym locus theologicus. Teistyczna interpretacja nauki nie sugeruje podporządkowania nauki teologii, bliższa jest raczej koncepcji harmonizacji tych dwóch rodzajów wiedzy.

\section{Pomiędzy popularyzacją wiedzy a krytyką poglądów Jana Jakuba Rousseau}

Już we wstępie swojej pierwszej rozprawy Sołtykowicz podkreślał, że zdobywanie wiedzy jest czynnością czasochłonna, której musza poświęcić się całe pokolenia, aby dojść do zaskakujących odkryć. Zdobywanie wiedzy jest dla autora jednoznaczne $\mathrm{z}$ dochodzeniem do prawdy, z poszukiwaniem episteme, w czym zdaje się on zbliżać do poglądów starożytnych filozofów.

Obok rozważań na temat skutków rozpowszechniania nauki, ważna jest refleksja na temat celu zdobywania wiedzy. Autor twierdzi, że kształcenie się powinno być użyteczne dla społeczeństwa, przynosić postęp ludzkości i umożliwiać człowiekowi panowanie nad siłami natury:

przymusiwszy Wodę Ogniem do władania ogromnymi Machinami na miejscu rąk ludzkich [...] przymusić powietrze do mełcia zboża, rznięcia drzewa, do gładzenia twardego marmuru, do podnoszenia wody na niedostępne dla niej miejsca, do bycia wielka pomocą w wymierzaniu Gór najwyższych i głębin [...] do dochodzenia zdrowości tego żywiołu i pewnych sposobów poprawienia onegoż, a zatem ocalenia życia tysiącom Ludzi ${ }^{44}$.

44 J. Sołtykowicz, Rozprawa nad przyczynami uwłaczajacych Naukom mniemań, odradzajacych się $w$ różnych Wiekach Świata, dz. cyt., s. 292-293. 
W poglądach takich widać nowoczesne spojrzenie przedstawiciela oświecenia, przekonanego o tym, że nauka jest niezbędnym elementem życia ludzi i dlatego warto ją pielęgnować. Jednocześnie Sołtykowicz poddawał pod dyskusję postulat nieprzekazywania wiedzy głębokiej i szczegółowej prostym ludziom i zarezerwowania jej jedynie do studiowania przez osoby uczone. Sięgajac do myśli starożytnych odnajdywał on porady, by prostym ludziom udostępniać naukę stosowną do wykonywanego przez nich zawodu, zaś wyjątkową wiedzę utrzymywać w tajemnicy. W swym dalszym wywodzie autor pisał, że z opisu licznych tyranów, którzy prześladowali filozofów, poetów i retorów, można wywnioskować, że niektórzy władcy bali się otaczać ludźmi mądrymi, widząc w nich zagrożenie. Kontrolowanie tłumu ludzi słabo wykształconych było dla nich znacznie wygodniejsze. Autor dziwi się jednak takiej postawie rządzących, wiedząc, że wielu z tych władców ceniło naukę i poświęcało swój czas na edukację. Być może w tej refleksji profesor Uniwersytetu Krakowskiego dostrzega swoje czasy, w których zaborcy dążąc do rozwoju naukowego i gospodarczego własnych krajów, jednocześnie blokowali postęp w Polsce. Ratunkiem dla tak osłabionego kraju mogą być - według filozofa - uczciwi i pilni nauczyciele, w ten sposób u zarania XIX wieku sformułowany został program wykorzystania nauki do celów zachowania polskości i walki o wolność ojczyzny. Wzory właściwego postępowania Sołtykiewicz znajdował w życiorysach poprzedników, którzy w XVI i XVIII wieku starali się popularyzować wiedzę, mając na uwadze wyłącznie szczere pobudki i chęć postępowania dla dobra ogółu. Za godny podziwu uważa profesor geniusz Kopernika, Galileusza i Newtona, chociaż wśród wykształconych zauważa autor także „niewdzięczne dzieci” ${ }^{45}$, które postęp chcą zachować tylko dla siebie, a dominacja intelektualna nad pozostałymi służy im, zgodnie z hasłem Machiavellego, do zwodzenia i oszukiwania innych ${ }^{46}$. Odrzucając makiaweliczny wzorzec użycia nauki autor opowiedział

45 J. Sołtykowicz, Rozprawa nad przyczynami uwłaczajacych Naukom mniemań, odradzajacych się $w$ różnych Wiekach Świata, dz. cyt., s. 301.

46 J. Sołtykowicz, Rozprawa nad przyczynami uwłaczajacych Naukom mniemań, odradzajacych się $w$ różnych Wiekach Świata, dz. cyt., s. 307. 
się za nauka, która ma realizować wysokie społeczne wartości, jak np. prawda i dobro.

W drugiej ze swoich rozpraw Sołtykowicz przekonywał, że działalność naukowca polegajacca na mówieniu prawdy nieakceptowanej przez otoczenie może być nawet przyczyną zagrożenia jego życia - czego doświadczył Sokrates i oskarżeni o herezję astronomowie XVI wieku. Pomimo tych zarzutów polski filozof postuluje propagowanie wiedzy wśród wszystkich ludzi. Ten postulat demokratyzacji wiedzy odpowiada wcześniejszym postulatom demokratyzacji nauczania wysuwanymi przez Komisję Edukacji Narodowej. W tym zakresie autor nie zgadza się ze starożytnymi myślicielami popierającymi elitaryzację nauki, twierdząc, że należy odróżniać „powinność” człowieka od „powinności” obywatela ${ }^{47}$. Poza tym był on przekonany, że filozoficzne rozważania na temat sensu życia, źródeł szczęścia czy pielęgnowania wartości moralnych nie mogą zaszkodzić patriotyzmowi. Dowodził nawet, że umiejętność połączenia pracy dla kraju z czerpaniem przyjemności z życia powinna charakteryzować każdego „obywatela i człowieka"48. Rozwiązanie kwestii społecznej roli nauki w kategoriach obywatelskich stanowi kolejny charakterystyczny rys oświeceniowej filozofii. Dalsza część rozważań zawiera wnioski z własnej obserwacji otaczającego świata. Sołtykowicz wysnuł wniosek, że wykonywanie określonego zawodu nie przeszkadza refleksjom na temat piękna przyrody i miejsca człowieka we wszechświecie, a zatem wiedza szczegółowa, w tym filozoficzna bez obaw może być przekazywana również ludziom słabiej wykształconym.

W swoich rozważaniach Sołtykowicz nawiązywał też do zyskującego popularność, nowego nurtu światopoglądowego, który z dzisiejszej perspektywy moglibyśmy zaliczyć do sentymentalizmu lub preromantyzmu. Ostro krytykował on Jana Jakuba Rousseau, twierdząc że niesłusznie oskarża on kulturę i naukę o zgubny wpływ na cywilizację, bo dzięki tym wartościom obserwujemy postęp ludzkości.

${ }^{47}$ J. Sołtykowicz, Dalszy ciag rozprawy nad przyczynami uwłaczajacych Naukom mniemań, „Rocznik Towarzystwa Naukowego z Uniwersytetem Krakowskim połączonego" V (1820), s. 108.

48 J. Sołtykowicz, Dalszy ciag rozprawy nad przyczynami uwłaczajacych Naukom mniemań, dz. cyt., s. 110. 
Przytaczał on poglądy autora Nowej Heloizy na temat zgubnego wpływu umiejętności na obyczaje, męstwo i miłość do ojczyzny, zaznaczając, że chociaż takie stanowisko nie jest nowatorskie to należy podkreślić jego fałszywość. Polski uczony oskarżył Rousseau o popędliwość, brak głębszej refleksji i celowe wprowadzanie czytelników w błąd dla zyskania sławy. Na potwierdzenie słuszności swoich racji Sołtykowicz odwoływał się do geniuszów Kopernika, Galileusza, Newtona i Kartezjusza, którzy swoim innowacyjnym sposobem myślenia udowodnili, że rozum odróżnia człowieka od zwierząt i jest podstawą rozwoju. Do poglądów francuskiego myśliciela nawiązywał Sołtykowicz również pod koniec drugiej rozprawy analizując stosowane przez Rousseau emocjonalne słownictwo. Członek TNK uważa, że takie wyrazy, jak „Powinność, Cnota, Męstwo, Miłość do Ojczyzny" ${ }^{49}$, skrywaja tak naprawdę przemoc i otumanienie człowieka. Autor Dyskursu o naukach $i$ sztukach oczernia w ten sposób cenione przez uczonych umiejętności, zarzucając im doprowadzenie ludzi do ateizmu. Sołtykowicz dopatruje się więc w poglądach Rousseau skrywanej manipulacji, czy nawet makiawelizmu. Na przykładzie tego badacza widać, że w środowisku TNK radykalnie odrzucono zapowiadające romantyzm podważanie wartości nauki. To ważny krok, w krystalizacji specyfiki krakowskiego ośrodka naukowo-filozoficznego.

\section{Sołtykowicza analiza antropologicznych źródeł negatywnego obrazu nauki}

Autor analizowanych rozpraw dostrzegał powody istnienia negatywnego obrazu nauki nie tylko w problemach zwiąanych z popularyzacją nauki i poglądami rozpowszechnianymi przez prekursora romantyzmu - Jana Jakuba Rousseau, ale także w budowie, ukształtowaniu samego człowieka. Rozważania na ten temat odnajdziemy w drugim wystapieniu Józefa Sołtykowicza, które rozpoczyna się

49 J. Sołtykowicz, Dalszy ciag rozprawy nad przyczynami uwłaczajacych Naukom mniemań, dz. cyt., s. 117. 
od omówienia przyczyn, jakie mogły doprowadzić do negatywnego postrzegania wiedzy. Krakowski uczony nie zaprzeczał temu, że nauka źle użyta może przynieść człowiekowi szkodę, ale jednocześnie zaznaczał, że nie powinien to być powód rezygnacji z postępu. Pomyłki takiego błędnego wykorzystania nauki wynikają z niedoskonałości ludzkiego umysłu i ciała. Ponownie sięgał Sołtykowicz w swojej argumentacji do historii filozofii, przytaczając przykłady ze starożytności, średniowiecza i nowożytności. Autor Rozprawy o przyczynach uwłaczajacych naukom mniemań jest przekonany, że pierwsi nauczyciele, nawet jeśli błądzili, to nie czynili tego świadomie. Wymieniając kolejne powody pozyskiwania fałszywej mądrości filozof podaje pychę i lenistwo człowieka. Uczony zadufany w sobie i dodatkowo pozbawiony chęci pracy łatwo da się zwieść pozorom prawdy, a postępując $\mathrm{w}$ ten sposób może się jeszcze przyczynić do wprowadzania w błąd kolejnych pokoleń. Dlatego tak ważnym jest, by podczas zdobywania wiedzy umiejętnie rozeznać się w poszukiwaniu prawdy i unikać fałszu, ale jednocześnie by nie rezygnować z czekającego nas trudu ze strachu przed możliwością popełnienia błędu:

A nie chcieć myśleć i dochodzić, aby nie błądzić, jest samoistnością naganna, jest nikczemnością bojaźliwościa, jest wyparciem się niejako użyczonego sobie daru rozumu. Usilnym albowiem, jako nas doświadczenie uczy, i niezmordowanym wpatrywaniem się w grubą zasłonę natury, coraz lepiej, acz po trochu, rozeznaje on [tj. człowiek - S.P.] to, czego szuka ${ }^{50}$.

Zachowując skromność, prawdziwy zwolennik mądrości powinien szanować dawnych uczonych, nawet jeśli jest przekonany o swojej racji. Odpowiada to obecnemu już w pierwszej rozprawie kumulatywistycznemu stanowisku, które docenia możliwość korzystania przez kolejne pokolenia badaczy z wiedzy już zdobytej przez ich poprzedników. Z drugiej jednak strony Sołtykowicz podaje przykłady z przeszłości (np. odkrycia Kopernika) dowodzące, że wiedza, która wydaje

50 J. Sołtykowicz, Dalszy ciag rozprawy nad przyczynami uwłaczajacych Naukom mniemań, dz. cyt., s. 89. 
się oczywistą i niekwestionowaną według współczesnych, może być uznana za nonsens przez kolejne pokolenia ${ }^{51}$. Autor akceptował zatem fakt zmienności nauki, która - tym razem zgodnie $\mathrm{z}$ antykumulacjonizmem - nie ma charakteru obiektywnego. Wydaje się zatem, że łączy on oba poglądy, zaznaczając w ten sposób, że szacunek dla dokonań dawnych badaczy należy zawsze łączyć z racjonalną ocena odpowiadajaca aktualnym wynikom badań. Nawet jednak w tej czynności, zgodnej z poglądami racjonalnymi i empirystycznymi, naukowiec powinien być ostrożny w konstruowaniu swoich osądów. Człowiek nie jest bowiem w stanie pozbyć się ograniczeń, jakie nakładają na niego umysł i ciało, które wciąż są niedoskonałymi narzędziami w poznawaniu otaczających nas świata i ludzi.

\section{Zakończenie}

Troszcząc się współcześnie o wieloaspektowy rozwój naszego kraju warto sięgnąc do historii, refleksji uczonych skąd płynie wniosek, że nauka ma istotny wpływ na rozwój gospodarki i oświaty ${ }^{52}$. Uświadomienie sobie jej społecznej roli i pozytywnego wpływu na życie ludzi jest szczególnie istotne dla poszanowania uczonych i ich pracy również w XXI wieku. Nieoceniona wartość profesjonalnych wykładowców i nauczycieli była szczególnie widoczna w Polsce po utracie niepodległości. Dla części myślicieli priorytetem było wówczas znalezienie rodaków, którzy poświęca się zdobywaniu wiedzy i uczynia to nawet bezinteresownie, a czasem z narażeniem się na represje. Najpoważniejszym bowiem problemem przy reorganizacji szkolnictwa, przed którym stanął Kołłątaj i jego współpracownicy, było obsadzenie katedr ${ }^{53}$. W sytuacji gdy profesorowie austriaccy opuszczali pośpiesznie Kraków Kołłątaj został zmuszony do reaktywowania

51 J. Sołtykowicz, Dalszy ciag rozprawy nad przyczynami uwłaczajacych Naukom mniemań, dz. cyt., s. 95.

${ }_{52}$ Patrz: B. Suchodolski, Kilka refleksji nad dziejami nauk przyrodniczych $w$ Polsce, dz. cyt., s. 30 .

${ }_{53}$ Patrz: J. Michalski, Warunki rozwoju nauki polskiej $w$ latach 1795-1862, dz. cyt., s. 127. 
profesorów - emerytów. Jednak wielu z nich chętnie przyjmowało stanowiska kierownicze na katedrach, ale bez zainteresowania prowadzeniem zajęć dydaktycznych. Był to szczególnie trudny okres dla istnienia Uniwersytetu Krakowskiego, gdyż - jak zauważa Jerzy Michalski - niskie kwalifikacje większości profesorów, brak ambicji, „atmosfera konfliktów i brak stabilizacji organizacyjnej i materialnej odbijały się bardzo niekorzystnie na najistotniejszej dla poziomu naukowego uczelni sprawie obsady katedr i wykonywania przez profesorów właściwych im obowiązków” ${ }^{54}$. W tym kontekście referaty o obronie nauki, jakie przed członkami Towarzystwa Naukowego Krakowskiego wygłosił Józef Sołtykowicz były niezwykle ważne. Autor podkreślał w nich bowiem ponadczasową wartość kształcenia się i szacunek dla mądrości jako największej zalety człowieka. Do jego - jak również Świątkowskiego - idei nawiążą przedstawiciele pozytywizmu, a później w okresie międzywojennym badacze problemu „nauki o nauce” ${ }_{55}$. Spadkobierców refleksji członka TNK dostrzega Bogdan Suchodolski w przedstawicielach Koła Naukoznawczego Kasy im. Mianowskiego, a szczególnie w osobach Marii i Stanisława Ossowskich ${ }^{56}$. W swojej refleksji filozoficznej Józef Sołtykowicz wyraźnie podkreślał szacunek dla dokonań poprzednich pokoleń, a jednocześnie akceptował zmienność wiedzy, jako konieczność na drodze do poznawania prawdy o świecie. W jego ujęciu nauka miała być wyrazem patriotyzmu, wypełnianiem woli Bożej, realizacja istniejącego w człowieku potencjału, ale miała służyć również przeciętnym obywatelom, być użyteczną i przyczyniać do poprawy bytu ludzi. Zdobywanie wiedzy jest również źródłem szczęścia, a także zbliżaniem się do Boga poprzez odkrywanie, ukrytego przez stwórcę, planu świata. Taki sposób postrzegania roli badacza i wartości nauki można odnaleźć nie tylko w pracy Sołtykowicza, ale także w dziełach innych przedstawicieli środowiska naukowego Krakowa.

${ }^{54}$ J. Michalski, Warunki rozwoju nauki polskiej $w$ latach 1795-1862, dz. cyt., s. 132 .

55 B. Suchodolski, Kilka refleksji nad dziejami nauk przyrodniczych $w$ Polsce, dz. cyt., s. 33.

56 B. Suchodolski, Kilka refleksji nad dziejami nauk przyrodniczych $w$ Polsce, dz. cyt., s. 33 . 
Zagadnienie to wymaga jednak dalszych badań nad historia myśli filozoficznej tego ośrodka - badań, do których skłania także sentencja umieszczana jako motto w roczniku TNK: „Scire tuum nihil est, nisi te scire hoc sciat alter” (,Twoja wiedza jest niczym, jeśli nie staje się udziałem innych").

\section{Summary}

The Enlightenment period vision of science by Josef Soltykowicz, as an example of philosophical reflection of Cracow Science Society (CSS)

The article concentrates on the analysis of the Enlightenment periods vision of science by Josef Sołtykowicz. His theories are examples of philosophical reflection of the Cracow Science Society. The starting point was the outline of the political and scientific situation from the second part of the XVII century to the first part of the XIX century also referring to the author's biography.

The main part of the article is the analysis of two Dissertations by Sołtykowicz published by the Cracow Science Society their yearly publication, in 1818 and 1820 .

The following points were taken into account: The roots of the society's activities, the relationship between science and faith, popularizing knowledge, criticism of Rousseau and anthropological analysis of the roots, of the negative view of knowledge. These theories are worth analysing, unfortunately so far the philosophical thought of the members of CSS, has not encouraged work on them as they deserved. At the same time we can expect that the work of the scientists from the CSS significantly impacted on the progress of the philosophical reflection in Cracow, and also the wider picture of modern polish scientific culture.

Keywords: Cracow Science Society (CSS), Enlightenment period philosophy, critics of J.J. Rousseau, science and faith, protection of science. 


\section{Bibliografia}

Gurgul H., Zarys historii fizyki. Od starożytności do XX wieku. Skrypt dla studentów fizyki, Szczecin 1993.

Heller M., Wstep do nowej filozofii przyrody, w: Filzofia i wszechświat. Wybór pism, Kraków 2012, s. 3-33.

Ludwisiak M., Postać Jana Jakuba Rousseau i jego wpływ na współczesnych, „Acta Universitatis Lodziensis. Folia Historica” 81 (2007), s. 87-108.

Michalski J., Warunki rozwoju nauki polskiej w latach 1795-1862, w: Historia nauki polskiej, t. III, red. B. Suchodolski, Wrocław 1977, s. 3-351.

Polak P., Między koniecznościa a utopia. Józefa Kremera koncepcja filozofii przyrody w kontekście szybko rozwijajacej się nauki w: Genus Vitae. Ksiega pamiatkowa dedykowana panu profesorowi Marianowi Józefowi Wnukowi, red. S. Janeczek, Z. Wróblewski, A. Starościc, Lublin 2019, s. 257-269.

Polak P., 19th Century Beginnings of the Kraków Philosophy of Nature, w: Philosophy in Science.Methods and Applications, Kraków 2011, s. 325-333.

Rederowa D., Powstanie $i$ ustrój Towarzystwa Naukowego Krakowskiego (1815-1872), „Kwartalnik Historii Nauki i Techniki” 14/1 (1969), s. 53-74.

Skoczyński J., Woleński J., Historia filozofii polskiej, Kraków 2010.

Skubała-Tokarska Z., Organizacja nauki w Polsce, w: Zarys dziejów nauk przyrodniczych $w$ Polsce, red. J. Kuryłowicz i in., Warszawa 1983, s. 37-95.

Sołtykowicz J., Rozprawa nad przyczynami uwłaczajacych naukom mniemań odradzajacych się $w$ różnych wiekach świata, „Rocznik Towarzystwa Naukowego z Uniwersytetem Krakowskim połączonego" III (1818), s. 246-312.

Sołtykowicz J., Dalszy ciag rozprawy o przyczynach uwłaczajacych naukom mniemań, „Rocznik Towarzystwa Naukowego z Uniwersytetem Krakowskim połączonego" V (1820), s. 77-135.

Suchodolski B., Kilka refleksji nad dziejami nauk przyrodniczych $w$ Polsce, w: Zarys dziejów nauk przyrodniczych w Polsce, red. J. Kuryłowicz i in., Warszawa 1983, s. 15-36.

Średniawa B., Część II. Reforma i jej nastepstwa, w: Historia filozofii przyrody i fizyki w Uniwersytecie Jagiellońskim, Warszawa 2001, s. 29-38.

Tatarkiewicz W., I. Filozofia w latach 1795-1830, w: Historia nauki polskiej, t. III, red. B. Suchodolski, Wrocław 1977, s. 355-371.

Wassik W., Historia filozofii polskiej, t. I, Warszawa 1958. 
Wąsik W., Historia filozofii polskiej, t. II, Warszawa 1966.

Wereszycka H., Orman-Michta E., Józef Florian Sołtykowicz, http://ipsb.nina. gov.pl/a/biografia/jozef-florian-soltykowicz (25.09.2018).

Wróblewski A. K., Historia fizyki od czasów najdawniejszych do współczesności, Warszawa 2006. 